Marine Policy

September 2016, Volume 71 Pages 157-165

http://dx.doi.org/10.1016/j.marpol.2016.05.031

http://archimer.ifremer.fr/doc/00341/45169/

(c) 2016 Elsevier Ltd. All rights reserved.

\title{
Ecosystem services assessment and compensation costs for installing seaweed farms
}

\author{
Cabral Pedro ${ }^{1,4,{ }^{*}}$, Levrel Harold ${ }^{2,6}$, Viard F. ${ }^{3}$, Frangoudes Katia ${ }^{4}$, Girard Sophie ${ }^{5}$, Scemama Pierre ${ }^{6}$ \\ ${ }^{1}$ NOVA IMS, Universidade Nova de Lisboa, 1070-312, Lisboa, Portugal \\ ${ }^{2}$ CIRED, AgroParisTech, 45 bis avenue de la Belle Gabrielle, 94736 Nogent-sur-Marne Cedex, France \\ ${ }^{3}$ Sorbonne Universités, UPMC Univ Paris 06, CNRS, UMR 7144, Lab. Adaptation et Diversité en Milieu \\ Marin, Team Div\&Co, Station Biologique de Roscoff, 29682 Roscoff, France \\ ${ }^{4}$ Université de Brest, UMR AMURE - Centre de droit et d'économie de la mer, IUEM, 12 rue du \\ Kergoat, CS 93837, 29238 Brest Cedex 3, France \\ ${ }^{5}$ Ifremer, Laboratoire de Biologie Halieutique (PDG-RBE-STH-LBH), Centre Bretagne - ZI de la Pointe \\ du Diable - CS 10070, 29280 Plouzané, France \\ ${ }^{6}$ Ifremer, UMR M101, AMURE, Unité d'Economie Maritime, BP 70, F-29280 Plouzané Cedex, France \\ * Corresponding author : Pedro Cabral, email address : pcabral@novaims.unl.pt
}

\begin{abstract}
:
In a global context of promotion and expansion of blue growth initiatives, the development of activities such as aquaculture calls for the assessment of the potential impacts on biodiversity at different levels and associated services. This paper presents an assessment of the potential impact of the installation of seaweed farms on ecosystem services and the induced compensation costs. Biophysical and socioeconomic indicators have been developed for helping decision makers to select the most suitable locations. The approach considers a multi-criteria approach based on Geographical Information Systems (GIS) and Habitat Equivalency Analysis (HEA). The former is used to obtain biophysical ecosystem services and socioeconomic indicators and the latter to evaluate the costs required to compensate the loss of cultural and provisioning ecosystem services. A case-study in the NormandBreton (Saint Malo) Gulf, France, illustrates this method through the analysis of hypothetical locations of seaweed farms. Results highlight the differences between alternative locations regarding biophysical constraints (in terms of distance and depth), potential risks of conflicts with existing uses, impacts on habitats and the ecosystem services delivered, and compensation costs. This case-study illustrates the flexibility of this approach which can be further adapted to include other indicators in order to deliver integrated information to coastal planners.
\end{abstract}

\section{Highlights}

- Seaweed farms installation requires a multi-criteria approach. A GIS-based methodology combined with HEA is proposed. We deliver integrated information about ES impacts and compensation costs. 
Keywords : Integrated marine policy, Habitat equivalency analysis, Compensation costs, No net loss, Blue growth

\section{Introduction}

The European Union (EU) Integrated Maritime Policy promotes the sustainable development of new blue growth activities [1], such as marine renewable energy, raw material extraction, leisure activities, and aquaculture including seaweed farming. Currently there are several on-going projects related to seaweed farming, for instance, the EnAlgae project (www.enalgae.eu) seeking to reduce reliance on fossil fuels by developing algal biofuel technologies, and the MARIBE project (www.maribe.eu) aiming to identify and develop business models for blue growth activities, including seaweed farming. Despite reports of several positive effects associated with seaweed farming worldwide [2-4], failures in or lack of knowledge exchange between the aquaculture industry, policymakers, local population, and people who depend on aquaculture, may jeopardize the 'Blue growth', which includes seaweed farming [5]. Additionally, it has also been reported that negative impacts of seaweed on ecosystems have not yet been fully investigated [6]. Altogether, these factors may contribute to the lack of social acceptance of this activity not only in France but also in other countries.

In France, seaweed farming activities started in the 1970-1980s, for instance, with the culture of Undaria pinnatifida, an introduced species native to Asia. Currently, there are 
ongoing projects such as IDEALG (www.idealg.ueb.eu) developing this sector by using local species (e.g. L. saccharina). Since 2008 this activity has gained new interest as a response to the crisis faced by oyster farmers due to the high mortality of oysters. The installation of seaweed farms along the French Atlantic coasts is now perceived as a source of complementary income to these farmers and gives new use to the existing oyster farms. However, not all of the available concessions are suitable for the cultivation of seaweed using subsurface long-lines, which should take place in deep waters rather than on the shore. Additionally, new projects of mussels or seaweed farms in deep waters are facing social resistance from local populations who fear negative impacts on ecosystems, fisheries activities and tourism, related to the degradation of seascape/seawater quality and increasing restrictions on recreational uses. Although the French administration has authorized new concessions, they have not been implemented due to the opposition of residents or associations.

To facilitate the development of these new activities, the European Commission urges countries to implement Marine Spatial Planning (MSP), which includes a consultation phase to identify the use of each marine zone. EU countries are also required to draw up a maritime spatial plan no later than 31 March 2021 [7]. However, considering the opposition faced by seaweed farming projects in France and other countries, it is necessary to go beyond simple spatial planning and to develop new concepts, methods, and tools to facilitate discussion and negotiation between the actors of the system.

The "ecosystem services" concept seems interesting to use for facilitating discussion at a territory scale (see for example the Natural Capital Project ${ }^{1}$ ). Marine ecosystems are complex and changing systems that provide multiple services to humans [8]. However, there is a recognized biodiversity crisis in marine environments, particularly in coastal zones where a diverse set of human activities and drivers are concentrated [9] and interact [10]. Services provided by marine systems have diminished while human exploitation patterns have been increasing [11]. One way of addressing this global problem is through ecosystem-based management (EBM) approaches, which propose managing seas and oceans by maintaining ecosystems structure, redundancies, and resilience to environmental changes [12]. EBM includes local political aspects and management actions at different spatial scales of application [13]. Despite the recognition of the interest in this approach at a global scale through the Millennium Ecosystem Assessment [8,14], successful examples of local EBM

\footnotetext{
${ }^{1} \mathrm{http}: / /$ www.naturalcapitalproject.org
} 
approaches are relatively rare [15]. EBM failures have different explanations, for instance, conflicts between users who expect or envision different benefits from ecosystems (e.g. commercial fishing versus conservation interests) or lack of institutions for effective governance [16-18], as well as level of transaction costs to overcome implementing this method [19]. Differences in terminology and knowledge among different groups of interests [20-22] coupled with the complexity and specificities of marine and coastal systems [23] make consultation in EBM a rough task. The use of the ecosystem services framework can help to improve the implementation of EBM approaches by providing a common set of facts and a common currency to better understand trade-offs between alternative development projects [15,24].

In addition to the concept of ecosystem services, it also seems important to adopt multicriteria methods for describing interactions between human uses and ecological dynamics (and not an aggregated monetary valuation). Indeed, the marine socio-ecosystem is characterized by multiple systems of values with multiple sustainability criteria which makes its governance a global challenge $[25,26]$. Thus, considering simultaneously the analysis of variables and values characterized by limited comparability is a task that can be assessed only using a multi-criteria analysis [27,28].

Three main dimensions associated with the location of implementation of seaweed farms were identified. First, seaweed farms face operational constraints, such as optimal depth, but also a minimal distance from the coast, which is directly associated to their visual impact. Second, marine ecosystems are subject to multiple uses, and locating farms where uses are already numerous increases the potential level of conflict among users. Third, the implementation of a new farm must be associated with an environmental impact assessment that can raise stakeholders' opposition but also lead to a mitigation procedure (avoiding, reducing, and compensating).

Adopting a multi-criteria analysis based on ecosystem services assessment requires innovative tools to provide useful information that can help the emergence of a general agreement. Two different tools were applied: i) the first tool is called InVEST (Integrated Valuation of Ecosystem Services and Trade-offs), which relies on ecological information to map, quantify, and value the distribution of ecosystem services across a landscape (or a seascape) [14,29,30]; and, (ii) the HEA (Habitat Equivalency Analysis), which has been used by the US administration in the case of accidental impacts on marine ecosystems and habitats to determine the size of a compensatory measure based on a biophysical ecosystem services unit criterion [31,32]. 
The goal of this paper is to provide biophysical and socioeconomic indicators describing

\subsection{Study area}

The Normand-Breton Gulf (GNB), located in the western part of the English Channel includes several habitats depending on complex currents and the presence of islands, archipelagos and rocky reefs [34] (Fig. 1). The Normandy and Brittany coasts are heterogeneous areas more developed and densely populated around the main urban centers of Ille-et-Vilaine and Côtes d'Armor, although less than along other French coasts such as the Mediterranean coasts [35]. There are 267 municipalities within a distance of $3 \mathrm{~km}$ of the coastline of the study area with a population of 600,340 inhabitants in 2011 [36]. However, these values do not consider the high number of tourists that visit the region mainly during the summer (e.g., more than 360,000 tourists visited the city of Saint-Malo in 2014 [37]). The existing marine economic activities include shellfish farming, commercial fishing, agriculture, tourism and leisure activities (e.g. sailing, diving, fishing, others), nuclear power and fuel reprocessing industries, aggregates extraction, and planned offshore renewable energy farms [35].

In this case study, biophysical, ecological, and socioeconomic indicators were calculated for three hypothetical locations, each one dedicated to the installation of seaweed farms of $1 \mathrm{~km}^{2}$ (A, B, and C). The locations were selected to allow a contrasting comparison of the different indicators that are going to be produced in this study. Although these are hypothetical locations, this exercise corresponds to a real need of the study area. A seaweed farming project ( 300 hectares) in the area of the GNB that has recently been approved by the 
administration is currently on hold because of the high level of conflict with the local population.

[Fig 1 here]

\subsection{Data and pre-processing}

A habitat map [37-48] using the European Nature Information System (EUNIS) [49] level 4 classification was used. In level 4 of the EUNIS classification scheme, 'physical' characteristics and biological zones are used as well as references to specific taxa; for instance major epifaunal taxa are used to discriminate rocky habitats although, for soft substrata, the classification is still based on the 'physical' and zonal attributes.

The ocean depth and the 12 nautical mile limits datasets were provided, respectively, by GEBCO [38] and Marine Regions [39].

Census data from the National Institute of Statistics and Economic Studies for year 2011 [36] at the "commune" level, the lowest unit of the French territorial administrative division, was used to estimate the number of inhabitants affected by the seaweed farms' potential location. The administrative boundaries are from the French National Geographic Institute [40]. The base land cover map of year 2006, the Corine Land Cover (CLC), is from the European Environmental Agency (EEA) and has a spatial resolution of $100 \mathrm{~m}$ with a minimum mapping unit of 25ha [41]. The Digital Elevation Model (DEM) used was ASTER [42] with a spatial resolution of $30 \mathrm{~m}$.

The geographical datasets of 17 recreational and professional activities were provided by the French Agency of Marine Protected Areas (AAMP) and the French Research Institute for Exploitation of the Sea (Ifremer). The source, type of geometry, and preprocessing activities with Geographical Information Systems (GIS) are described in Table A.1 of Annex 1. All of the geographical datasets are, or were, converted into a common NTF France II (Degrees) projection.

\subsection{Methods}

The methodological approach for providing indicators for the installation of seaweed farms is depicted in Figure 2 and described below.

[Fig 2 here] 


\subsubsection{Biophysical constraints: distance from the coast and visual impact}

The biophysical criteria include aspects that facilitate the installation of the seaweed farms such the depth, the distance from the coast, and the visual impact of the infrastructures on the population living near the coast. GIS tools and models available in, respectively, ESRI's ArcGIS [43] and InVEST software from Natural Capital Project [44] were used to obtain the biophysical factors.

The optimal depth for seaweed cultivation with subsurface long-lines was defined to be between 6 and $15 \mathrm{~m}$. This depth is the same used for a real seaweed farm project, with Saccharina latissima, in Plobannalec-Lesconil and Loctudy, in Brittany [45]. Since these infrastructures need to be permanently under water, only the areas outside the foreshore were considered.

Other important aspects considered were the distance of the infrastructure from the coast and the visual impact and restrictions to recreation activities (e.g. sailing, scuba diving, others) caused by the buoys and lines of the infrastructures. Within the 12 nautical mile limit, the closer the infrastructures are to the coast, the less important are the economic costs related to their exploitation, e.g., lower transportation costs. On the other hand, the closer the infrastructures are to the coast, the higher will be the potential visual impact on the population that lives near the coast and the higher will be restrictions for recreational activities in the areas occupied by the infrastructures, thus decreasing the social acceptance to this type of economic activity. An estimate of the potential number of inhabitants affected by each seaweed farm is provided using the InVEST Scenic Quality Model [44]. This model includes the use of a dasymetric technique to represent population density more truthfully by combining census population data with the urban land use and cover classes [46].

\subsubsection{The potential use conflicts}

The identification of the areas of potential use conflicts with the new infrastructures is an important socioeconomic factor. The potential use conflicts are likely to arise more frequently in the areas where more human activities co-exist. Thus, these areas should be avoided to install the seaweed farms. The human activities, represented by separate geographical layers, were counted using a $1 \mathrm{~km}$ spatial resolution cell by the InVEST Overlap tool [44] to compute a "potential conflict" score. Legal aspects, such as the access to the maritime space, through 
the allocation of concessions, or the existing rules for cultivating only species found locally may also limit the installation of the seaweed farms [47,48]. However, these were not considered in this hypothetical exercise.

\subsubsection{Impacts on ecosystem services}

Although there are more ecosystem services provided by the GNB habitats, the provision and cultural ecosystem services listed in Table 1 were the ones selected as the most relevant and documented for this study.

Biodiversity is here treated as a cultural service and concerns only the GNB notable species. The regulating and maintenance services were also identified for the study area. However, and despite their potential impact on climate change and mitigation against global warming or on macrofaunal and seagrass assemblages [49-53], these were not considered in this study due to the lack of suitable data.

[Table 1 here]

To study the impact on ecosystem services, a matrix that links the 17 EUNIS level 4 habitats to the availability of the ecosystem services listed in Table 1 was created using expert knowledge [27]. This procedure included the analysis of 18 commercial species for food provision services and 14 activities for cultural services. The scores reflected the availability of ecosystem services provided by the habitats for each type of service and could have the values of 0 (absent), 1 (weak), 2 (medium), or 3 (strong). All values were summed and transformed into an interval between 0 and 1, by subtracting the minimum value and dividing by the difference between the maximum and minimum value [54]. This information was used to build maps of ecosystem services availability in the GNB on a grid of $1 \mathrm{~km}$ spatial resolution. More details about this dataset are available in [27].

\subsubsection{Compensation costs regarding impacts on ecosystem services}

The compensation cost of the creation of seaweed farms from the ecosystem services approach [55] were assessed using the MEA categories [8]: cultural, provisioning, and regulating services. The Habitat Equivalency Analysis (HEA), which allows to calculate equivalencies between damage and compensation, in biophysical units corresponding to proxies of ecosystem services [32], was also used. The basis of this method was introduced in 
1994 by American scientists in order to address the problem of monetary valuation of [56-58]. In 1995, the National Oceanic and Atmospheric Administration of the United States released a report on HEA that was subsequently revised [31].

The Visual HEA software [59], version 2.6, was used to apply the HEA method. A more detailed description of this method can be obtained in the works by $[32,55,60]$. The selection of ecosystem indicators was carried out by experts with extensive scientific knowledge on the GNB and was based on the intensity of presence of selected species for each of the existing habitats. The species that exhibited the greatest intensity of presence were used as proxies for ecosystem services indicators. These ecosystem services indicators comprise the selection of adequate metrics, such as growth rate/cm of oysters as a proxy of provisioning services [55]. The number of hectares is the metric used in the equivalency method for each ecosystem service. The losses due to impacts and the gains due to compensation are presented as Discounted Service Acre-Years (DSAYs). A widely accepted rate of 3\% was used to make past and future losses and gains comparable [55,61].

The compensatory ratios used by the US Natural Resources Damage Assessment (NRDA) $[55,62]$ are used in this study. A ratio represents the number of units of compensatory area necessary to compensate one unit of natural area. In this case-study it is assumed that the concession starts in year 2015 and ends in 2030 (Fig. 3). The pre-injury service level is 100\% and there is a loss of $100 \%$ as a consequence of the seaweed farm installation. When the concession ends, the service level is restored to $100 \%$.

[Fig 3 here]

The compensation action starts in year 2015 and reaches a maximum of $85 \%$ because it is assumed that it is not possible to recover as efficiently as Nature does. The recovery time is variable and depends on the selected proxy. Figure 4 shows the recovery time for the maerl beds.

[Fig 4 here] 
The area of the damaged zone, in this case the seaweed farm location, is known, i.e. $1 \mathrm{~km}^{2}$. The gains obtained with the compensation measures were then quantified. The size of the compensation project is obtained after calculating the maintenance costs (ha to compensate/impacted area). Finally, the maintenance costs (in \$/impacted ha) are estimated according to specific habitats. The recovery times (years), ratios, and restoration costs of the proxies used as ecosystem services indicators were obtained through bibliographic research.

\section{Results}

A mask with the suitable biophysical characteristics (i.e., depth, distance to coastline, habitat, within the 12 nautical miles, and visual impact) delimiting the suitable area for the seaweed farm was created. Subsequently, the InVEST Overlap Analysis tool was used to calculate the number of human activities existing in a grid of $1 \mathrm{~km}$ spatial resolution (Fig. 5). The maximum number of overlapping activities is five and lowest is one.

[Fig 5 here]

Figure 6 depicts using a $1 \mathrm{~km}$ spatial resolution cell, the ecosystem services availability for each type of ecosystem services. The closer the values are to 0 the lower is the ecosystem services availability by type of service. One would give priority to install seaweed farms in the areas where there is less availability of ecosystem services to cause the minimum possible impact on the existing level of ecosystem services.

[Fig 6 here]

Table 2 shows the types of habitat existing in each seaweed farm location. Farms A and B are located over a single type of habitat, respectively, maerl bed (A5.51) and circalittoral coarse sediment (A5.13). Farm C has 38.4\% of its area located over polychaete/bivalvedominated muddy sand shores (A2.24). The remaining area of this farm is located in infralittoral mixed sediments (A5.43).

The species selected as proxies of ecosystem services were the ones that had the highest abundance according to expert knowledge and fall into the categories of cultural or provisioning ecosystem services. 
The adopted recovery times (years), ratios, and restoration costs of the proxies used as ecosystem services indicators are shown in Table 3.

[Table 3 here]

Using Visual_HEA, the following results were obtained for the maerl:

- 13,132 DSAYs are lost in the damaged area.

- 15,243 DSAYs are gained in the compensatory area.

- Using a 3:1 ratio, the HEA shows that 2.585 ha of maerl beds are necessary to compensate for the 1 ha of the damaged area.

The cost of coral reefs restoration programs as an approximation of maintenance costs of maerl beds, which have very similar characteristics [55], was used. According to [63], this cost ranges from $\$ 24,700$ to $\$ 123,548$ per ha. Converting this range of values to $\mathrm{km}^{2}$ and multiplying it by the number of ha needed to compensate one damaged ha (2.585) would be an approximation of what should be paid by the seaweed farmer to compensate the creation of farm A (i.e., between $\$ 6,384,950$ and $\$ 31,937,158$ ). The same reasoning was applied for the other farm locations. For the farm location $C$, the costs were calculated using the values provided by [63] mollusk reefs. Results for all the farms, together with the biophysical, ecological, and socioeconomic indicators obtained are shown in Table 4. 
[Table 4 here]

Farm A presents the best values for three indicators: the lowest level of provisioning services (42\%) and cultural services (20\%) in the site and the lowest visual impact (3690 inhab.). However, it is by far the one that presents the highest compensation costs, between $\$ 6,384,950$ and $\$ 31,937,158$. It is also the one in which the number of ha to be compensated per damaged ha is the highest (2.585). Farm B is the best for two indicators: potential human use conflicts (one activity) and restoration costs $(\$ 365,484)$. Farm $\mathrm{C}$ is the closest to the coast $(1 \mathrm{~km})$ and the one which presents the lowest number of ha to be compensated per damaged ha (2.002). However, it is located in an area where a high number of potential conflicts may arise (five activities) (as with farm A). It is also an area where cultural activities are very available (100\%).

\section{Discussion and conclusions}

An EBM approach was proposed to provide quantitative biophysical, ecological and socioeconomic indicators to help marine planners decide on where to create seaweed farms in the GNB. The aim was to provide an approach that supports decision making enabling an informed discussion between administration and local stakeholders during the installation of new aquaculture projects. Being the best in three out of seven indicators, farm A could be seen as the "best" location. However, criteria may have different levels of importance and weighted differently according to the context. This issue should be addressed by stakeholders during the discussion phase by providing feedback on the relative importance of each indicator, allowing them to rank the location of the seaweed farms.

The novelty of this explicit spatial approach to ecosystem services impacts and compensation costs resides in the delivery of this information in an integrated way that can be easily adapted to include more constraints and/or other ecosystem services. To do this a multicriteria approach combining different tools to inform four identified dimensions was used. Multi-criteria methods provide a systematic methodology to combine different inputs to help rank project alternatives, and there has been an important increase in the literature about these methods [65]. This interest can be explained as it brings transparency to decisions involving a high level of complexity.

Two different tools were used. First, the InVEST tool, developed by the Natural Capital Project, which uses information about the characteristics of the ecosystem to determine the 
delivery of different ecosystem services [29] was applied. This approach is based on the identification of ecological production functions that specify the feasible output of ecosystem services given the biophysical characteristics of an ecosystem [14]. InVEST has been designed to be integrated into stakeholders' consultation through the co-designing of scenarios to project how the provision of ecosystem services might change in response to different development decisions [24]. As the number of modeling tools is high, InVEST offers the advantage being relatively easy to implement when data are available [66]. Second, the HEA tool to determine the surface and cost of compensatory measures associated with the impact of seaweed farm implementation was applied. This tool relies on the use of bioecological proxies to determine equivalency between losses due to impact and gains due to compensation. It has been developed to simplify the calculation of costs that a polluter has to pay in a context of strong opposition of stakeholders against a court decision that was earlier based on contingent valuation [58]. One of the strengths of the method is to focus negotiation on the choice of a single metric that best captures the level of ecosystem services, since results will strongly vary according to this choice $[67,68]$. Experiences of stakeholders' implication into the metrics selection have been realized using an ecosystem services framework [55].

In the end our analysis summarizes the relevant information needed for decision-making in the perspective of four identified issues. The combination of these tools has the potential to support decision makers to reach consensus among different stakeholders, since all tools rely on the ecosystem services framework that allows the use of a common currency to the different types of benefits users will receive from an ecosystem. Additionally, the tools have been built in a manner to integrate stakeholders' concerns and bring consultation back into decision.

Nevertheless, there are limitations that one must be aware of when using this approach. An important one was the option of using ecosystem indicators through single representative species instead of the whole ecosystem (for the HEA tool). And yet, changes at population level have been shown to have a substantial impact on the ecosystem function as a whole $[69,70]$. Other neglected aspects were the complexity of the interactions that exist between species and habitats [71] and the exclusion from this study of regulating services that could have positive or negative impacts on several ecosystem services [49-53]. Regarding this last aspect, it is worth mentioning that a recent study considered negligible the impact of seaweed farms on these services [72]. None of these limitations were not possible to address, due to insufficient data or knowledge needed to use these approaches. 
Regarding the compensation costs, although these vary in space and over time, the lack of

\section{References}

[1] CEC, European Commission Communication from the Commission to the European parliament, the Council, the European economic and social committee and the Committee of the Regions - An Integrated Maritime Policy for the European Union, (2007).

[2] L. Sievanen, B. Crawford, R. Pollnac, C. Lowe, Weeding through assumptions of livelihood 
approaches in ICM: Seaweed farming in the Philippines and Indonesia, Ocean Coast. Manag. 48 (2005) 297-313. doi:10.1016/j.ocecoaman.2005.04.015.

[3] I.K. Chung, J. Beardall, S. Mehta, D. Sahoo, S. Stojkovic, Using marine macroalgae for carbon sequestration: a critical appraisal, J. Appl. Phycol. 23 (2011) 877-886. doi:10.1007/s10811010-9604-9.

[4] H. Ye, K. Wang, C. Zhou, J. Liu, X. Zeng, Purification, antitumor and antioxidant activities in vitro of polysaccharides from the brown seaweed Sargassum pallidum, Food Chem. 111 (2008) 428-432. doi:10.1016/j.foodchem.2008.04.012.

[5] G. Krause, C. Brugere, A. Diedrich, M.W. Ebeling, S.C.A. Ferse, E. Mikkelsen, et al., A revolution without people? Closing the people-policy gap in aquaculture development, Aquaculture. 447 (2015) 44-55. doi:10.1016/j.aquaculture.2015.02.009.

[6] M.S. Thomsen, T. Wernberg, A.H. Engelen, F. Tuya, M.A. Vanderklift, M. Holmer, et al., A Meta-Analysis of Seaweed Impacts on Seagrasses: Generalities and Knowledge Gaps, PLoS One. 7 (2012) e28595. doi:10.1371/journal.pone.0028595.

[7] EC, Directive 2014/89/EU of the European Parliament and of the Council of 23 July 2014 establishing a framework for maritime spatial planning, (2014). http://eurlex.europa.eu/legal-content/GA/TXT/?uri=celex:32014L0089.

[8] MEA, Rapport de synthèse de l'Évaluation des Écosystèmes pour le Millénaire, Millennium Ecosystem Assessment, Island Press, Washington, DC, 2005. http://www.unep.org/maweb/documents/document.447.aspx.pdf.

[9] B.S. Halpern, M. Frazier, J. Potapenko, K.S. Casey, K. Koenig, C. Longo, et al., Spatial and temporal changes in cumulative human impacts on the world's ocean, Nat. Commun. 6 (2015) 7615. doi:10.1038/ncomms8615.

[10] C.M. Crain, K. Kroeker, B.S. Halpern, Interactive and cumulative effects of multiple human stressors in marine systems, Ecol. Lett. 11 (2008) 1304-1315. doi:10.1111/j.14610248.2008.01253.x.

[11] S.A. Levin, J. Lubchenco, Resilience, Robustness, and Marine Ecosystem-based Management, Bioscience. 58 (2008). doi:10.1641/B580107.

[12] M. Ruckelshaus, T. Klinger, N. Knowlton, D.P. DeMASTER, Marine Ecosystem-based Management in Practice: Scientific and Governance Challenges, Bioscience. 58 (2008). doi:10.1641/B580110.

[13] S.E. Lester, K.L. McLeod, H. Tallis, M. Ruckelshaus, B.S. Halpern, P.S. Levin, et al., Science in support of ecosystem-based management for the US West Coast and beyond, Biol. Conserv. 143 (2010) 576-587. doi:10.1016/j.biocon.2009.11.021.

[14] H. Tallis, S. Polasky, Mapping and Valuing Ecosystem Services as an Approach for Conservation and Natural-Resource Management, Ann. N. Y. Acad. Sci. 1162 (2009) 265-283. doi:10.1111/j.1749-6632.2009.04152.x.

[15] E.F. Granek, S. Polasky, C. V. Kappel, D.J. Reed, D.M. Stoms, E.W. Koch, et al., Ecosystem Services as a Common Language for Coastal Ecosystem-Based Management, Conserv. Biol. 24 (2010) 207-216. doi:10.1111/j.1523-1739.2009.01355.x.

[16] E. Ostrom, Governing the Commons The Evolution of Institutions for Collective Action, 
Political, Cambridge University Press, Cambridge, United Kingdom, 1990.

[17] T.M. Hennessey, Governance and adaptive management for estuarine ecosystems: The case of Chesapeake Bay, Coast. Manag. 22 (1994) 119-145. doi:10.1080/08920759409362225.

[18] L.B. Crowder, SUSTAINABILITY: Resolving Mismatches in U.S. Ocean Governance, Science (80-. ). 313 (2006) 617-618. doi:10.1126/science.1129706.

[19] H. Levrel, M. Bouamrane, Instrumental learning and indicators efficiency: outputs from coconstruction experiments in West African biosphere reserves, Ecol. Soc. 13 (2008) 28. http://www.ecologyandsociety.org/vol13/iss1/art28/.

[20] F. Berkes, C. Folke, Linking social and ecological systems: management practices and social mechanisms for building resilience, Cambridge University Press, Cambridge, United Kingdom, 1998.

[21] P. Weeks, J.M. Packard, Acceptance of Scientific Management by Natural Resource Dependent Communities. Aceptacion del Manejo Cientifico por Comunidades Dependientes de Recursos Naturales, Conserv. Biol. 11 (1997) 236-245. doi:10.1046/j.15231739.1997.95433.x.

[22] D.W. Cash, W.C. Clark, F. Alcock, N.M. Dickson, N. Eckley, D.H. Guston, et al., Knowledge systems for sustainable development, Proc. Natl. Acad. Sci. 100 (2003) 8086-8091. doi:10.1073/pnas.1231332100.

[23] M.P. Weinstein, R.C. Baird, D.O. Conover, M. Gross, J. Keulartz, D.K. Loomis, et al., Managing coastal resources in the 21st century, Front. Ecol. Environ. 5 (2007) 43-48. doi:10.1890/15409295(2007)5[43:MCRITS]2.0.CO;2.

[24] G.C. Daily, S. Polasky, J. Goldstein, P.M. Kareiva, H.A. Mooney, L. Pejchar, et al., Ecosystem services in decision making: time to deliver, Front. Ecol. Environ. 7 (2009) 21-28. doi:10.1890/080025.

[25] European Commission, Proposal for a Directive of the European Parliament and of the Council establishing a framework for maritime spatial planning and integrated coastal management, (2013). http://eur-lex.europa.eu/LexUriServ/LexUriServ.do?uri=COM:2013:0133:FIN:EN:PDF.

[26] UNEP, Marine and coastal ecosystems and human well-being: synthesis, United Nations Environment Programme, Nairobi, Kenya, 2006.

[27] P. Cabral, H. Levrel, J. Schoenn, E. Thiébaut, P. Le Mao, R. Mongruel, et al., Marine habitats ecosystem service potential: A vulnerability approach in the Normand-Breton (Saint Malo) Gulf, France, Ecosyst. Serv. 16 (2015) 306-318. doi:10.1016/j.ecoser.2014.09.007.

[28] J. Martinez-Alier, G. Munda, J. O'Neill, Weak comparability of values as a foundation for ecological economics, Ecol. Econ. 26 (1998) 277-286. doi:10.1016/S0921-8009(97)00120-1.

[29] E. Nelson, G. Mendoza, J. Regetz, S. Polasky, H. Tallis, Dr. Cameron, et al., Modeling multiple ecosystem services, biodiversity conservation, commodity production, and tradeoffs at landscape scales, Front. Ecol. Environ. 7 (2009) 4-11. doi:10.1890/080023.

[30] A.D. Guerry, M.H. Ruckelshaus, K.K. Arkema, J.R. Bernhardt, G. Guannel, C.-K. Kim, et al., Modeling benefits from nature: using ecosystem services to inform coastal and marine spatial planning, Int. J. Biodivers. Sci. Ecosyst. Serv. Manag. 8 (2012) 107-121. doi:10.1080/21513732.2011.647835. 
[31] NOAA, Habitat Equivalency Analysis: An Overview, Washington, DC, 2000.

http://www.darrp.noaa.gov/library/pdf/heaoverv.pdf.

[32] R.W. Dunford, T.C. Ginn, W.H. Desvousges, The use of habitat equivalency analysis in natural resource damage assessments, Ecol. Econ. 48 (2004) 49-70.

doi:10.1016/j.ecolecon.2003.07.011.

[33] LMAP, LOI n 2010-874 du 27 juillet 2010 de modernisation de l'agriculture et de la pêche. Source: Legifrance, (2010).

http://www.legifrance.gouv.fr/affichTexte.do?cidTexte=JORFTEXT000022521587\&categorieLi en=id (accessed November 20, 2015).

[34] P. Le Mao, Le golfe Normand-Breton: définitions et caractéristiques. un site a la riche histoire naturaliste et scientifique, in: Rollet, C. et Dedieu, K., 2011: p. 174-pp.

[35] VALMER, Valuing Ecosystem Services in the Western Channel, VALMER. (2014). http://www.valmer.eu.

[36] INSEE, Historique des populations par commune depuis 1961, Institut national de la statistique et des études économiques, Popul. Légales 2011. (2014). http://www.insee.fr/.

[37] S.-M. Tourisme, Rapport d'activité 2014, Saint-Malo, France, 2014.

[38] GEBCO, General Bathymetric Chart of the Oceans (GEBCO), (2014). http://www.gebco.net/.

[39] S. Claus, B. Hauwere, B. Vanhoorne, F. Souza Dias, F. Hernandez, J. Mees, MarineRegions.org, Flanders Mar. Inst. (2014). http://www.marineregions.org/.

[40] IGN, GEOFLA ${ }^{\circledast}$ Communes, Institut national de l'information géographique et forestière, (2013). http://professionnels.ign.fr/.

[41] EEA, Corine Land Cover 2006, European Environment Agency (EEA), (2012). http://www.eea.europa.eu/data-and-maps/data/corine-land-cover-2006-raster-2\#tabmetadata.

[42] NASA, ASTER Global Digital Elevation Map, (2012). http://asterweb.jpl.nasa.gov/gdem.asp.

[43] ESRI, ArcGIS, (2014). www.esri.com.

[44] H. Tallis, T. Rickets, A. Guerry, S. Wood, R. Sharp, E. Nelson, et al., InVEST 3.1.1 User's Guide: Integrated Valuation of Environmental Services and Tradeoffs. The Natural Capital Project, (2016). http://ncp-dev.stanford.edu/ dataportal/investreleases/documentation/current_release/.

[45] Algolesko, Déclaration au titre de l'article R214-32 du code de l'Environnement, Tome 1, (2013) 65. http://sioca.fr/documents/la-gestion-integree-des-zones-cotieres/etudes-20122014/1744-projet-algolesko (accessed July 1, 2015).

[46] R. Sleeter, M. Gould, GIS Software to Remodel Population Data Using Dasymetric Mapping Methods, United States Geological Survey, 2007. http://pubs.usgs.gov/tm/tm11c2/tm11c2.pdf.

[47] CSRPN, Avis du conseil scientifique régional du patrimoine naturel (CSRPN) de Bretagne №2013-10 Espèces Natura 2000, Liste des espèces d'algues éligibles à l'algoculture dans les schémas des structures conchylicoles, (2013). 
[48] L. Antoine, M. Lemoine, S. Boulben, R. Kaas, M. Laurans, F. Viard, et al., Emergence d'une filière de culture de macro-algues en Bretagne et problème relatif à une espèce non indigène, le wakame (Undaria pinnatifida), (2012). http://archimer.ifremer.fr/doc/00086/19740/ (accessed November 21, 2015).

[49] J.S. Eklöf, M. de la Torre Castro, L. Adelsköld, N.S. Jiddawi, N. Kautsky, Differences in macrofaunal and seagrass assemblages in seagrass beds with and without seaweed farms, Estuar. Coast. Shelf Sci. 63 (2005) 385-396. doi:10.1016/j.ecss.2004.11.014.

[50] I.K. Chung, J.H. Oak, J.A. Lee, J.A. Shin, J.G. Kim, K.-S. Park, Installing kelp forests/seaweed beds for mitigation and adaptation against global warming: Korean Project Overview, ICES J. Mar. Sci. 70 (2013) 1038-1044. doi:10.1093/icesjms/fss206.

[51] D.A. Smale, M.T. Burrows, P. Moore, N. O'Connor, S.J. Hawkins, Threats and knowledge gaps for ecosystem services provided by kelp forests: a northeast Atlantic perspective., Ecol. Evol. 3 (2013) 4016-38. doi:10.1002/ece3.774.

[52] K.C. Bergman, S. Svensson, M.C. Öhman, Influence of Algal Farming on Fish Assemblages, Mar. Pollut. Bull. 42 (2001) 1379-1389. doi:10.1016/S0025-326X(01)00168-0.

[53] E.J. Hehre, J.J. Meeuwig, Differential Response of Fish Assemblages to Coral Reef-Based Seaweed Farming, PLoS One. 10 (2015) e0118838. doi:10.1371/journal.pone.0118838.

[54] V. Parravicini, A. Rovere, P. Vassallo, F. Micheli, M. Montefalcone, C. Morri, et al., Understanding relationships between conflicting human uses and coastal ecosystems status: A geospatial modeling approach, Ecol. Indic. 19 (2012) 253-263. doi:10.1016/j.ecolind.2011.07.027.

[55] A.-C.C. Vaissière, H. Levrel, C. Hily, D. Le Guyader, Selecting ecological indicators to compare maintenance costs related to the compensation of damaged ecosystem services, Ecol. Indic. 29 (2013) 255-269. doi:10.1016/j.ecolind.2013.01.003.

[56] M. Mazzotta, J. Opaluch, T. Grigalunas, Natural resource damage assessment: The role of resource restoration, Nat. Resour. J. 34 (1994) 153-178.

[57] R.E. Unsworth, R.C. Bishop, Assessing natural resource damages using environmental annuities, Ecol. Econ. 11 (1994) 35-41. doi:10.1016/0921-8009(94)90048-5.

[58] D.B. Thompson, Valuing the Environment: Courts' Struggles with Natural Resource Damages, SSRN Electron. J. (2002). doi:10.2139/ssrn.306319.

[59] K.E. Kohler, R.E. Dodge, Visual_HEA: Habitat Equivalency Analysis software to calculate compensatory restoration following natural resource injury, in: Proc. 10th Int. Coral Reef Symp., 2006: pp. 1611-1616.

[60] M. Zafonte, S. Hampton, Exploring welfare implications of resource equivalency analysis in natural resource damage assessments, Ecol. Econ. 61 (2007) 134-145. doi:10.1016/j.ecolecon.2006.02.009.

[61] W.D. Shaw, M. Wlodarz, Ecosystems, ecological restoration, and economics: does habitat or resource equivalency analysis mean other economic valuation methods are not needed?, Ambio. 42 (2013) 628-43. doi:10.1007/s13280-012-0351-9.

[62] S. Pioch, Mesures compensatoires dans les écosystèmes marins en Floride. Exemple et expériences d'aménagements pour la production de services écosystémiques, IFREMER, NSU, 
Agence des AMP, CDC Biodiversité., 2010.

[63] B. Roach, W.W. Wade, Policy evaluation of natural resource injuries using habitat equivalency analysis, Ecol. Econ. 58 (2006) 421-433. doi:10.1016/j.ecolecon.2005.07.019.

[64] F. Alban, F. Kervarec, G. Le Lec, P. Le Floc'h, J. Boncoeur, L'impact socioéconomique du programme de production artificielle de coquilles Saint-Jacques en rade de Brest, UBO, CEDEM, 2001.

[65] I.B. Huang, J. Keisler, I. Linkov, Multi-criteria decision analysis in environmental sciences: Ten years of applications and trends, Sci. Total Environ. 409 (2011) 3578-3594. doi:10.1016/j.scitotenv.2011.06.022.

[66] K.L. Vigerstol, J.E. Aukema, A comparison of tools for modeling freshwater ecosystem services, J. Environ. Manage. 92 (2011) 2403-2409. doi:10.1016/j.jenvman.2011.06.040.

[67] E. Strange, H. Galbraith, S. Bickel, D. Mills, D. Beltman, J. Lipton, Determining Ecological Equivalence in Service-to-Service Scaling of Salt Marsh Restoration, Environ. Manage. 29 (2002) 290-300. doi:10.1007/s00267-001-0019-X.

[68] P. Scemama, H. Levrel, Using Habitat Equivalency Analysis to Assess the Cost Effectiveness of Restoration Outcomes in Four Institutional Contexts, Environ. Manage. (2015). doi:10.1007/s00267-015-0598-6.

[69] J. Brodersen, O. Seehausen, Why evolutionary biologists should get seriously involved in ecological monitoring and applied biodiversity assessment programs., Evol. Appl. 7 (2014) 968-83. doi:10.1111/eva.12215.

[70] C.M. Duarte, Marine biodiversity and ecosystem services: an elusive link, J. Exp. Mar. Bio. Ecol. 250 (2000) 117-131. doi:10.1016/S0022-0981(00)00194-5.

[71] B.K. Eriksson, A. Rubach, H. Hillebrand, Biotic habitat complexity controls species diversity and nutrient effects on net biomass production, Ecology. 87 (2006) 246-254. doi:10.1890/050090.

[72] Algolesko, Etude d'incidences au titre de Natura 2000, Tome 2, (2013) 34. http://sioca.fr/documents/la-gestion-integree-des-zones-cotieres/etudes-2012-2014/1744projet-algolesko (accessed July 1, 2015). 
ANNEX 1

[Table A.1 here]

1

13

14

15

16

17

18

19

20

21

22

23

24

25

26

27

28

29

30

31

32

33

34

35

36

37

38

39

40

41

42

43

44

45

46

47

48

49

50

51

52

53

54

55

56

57

58

59

60

61

62

63 


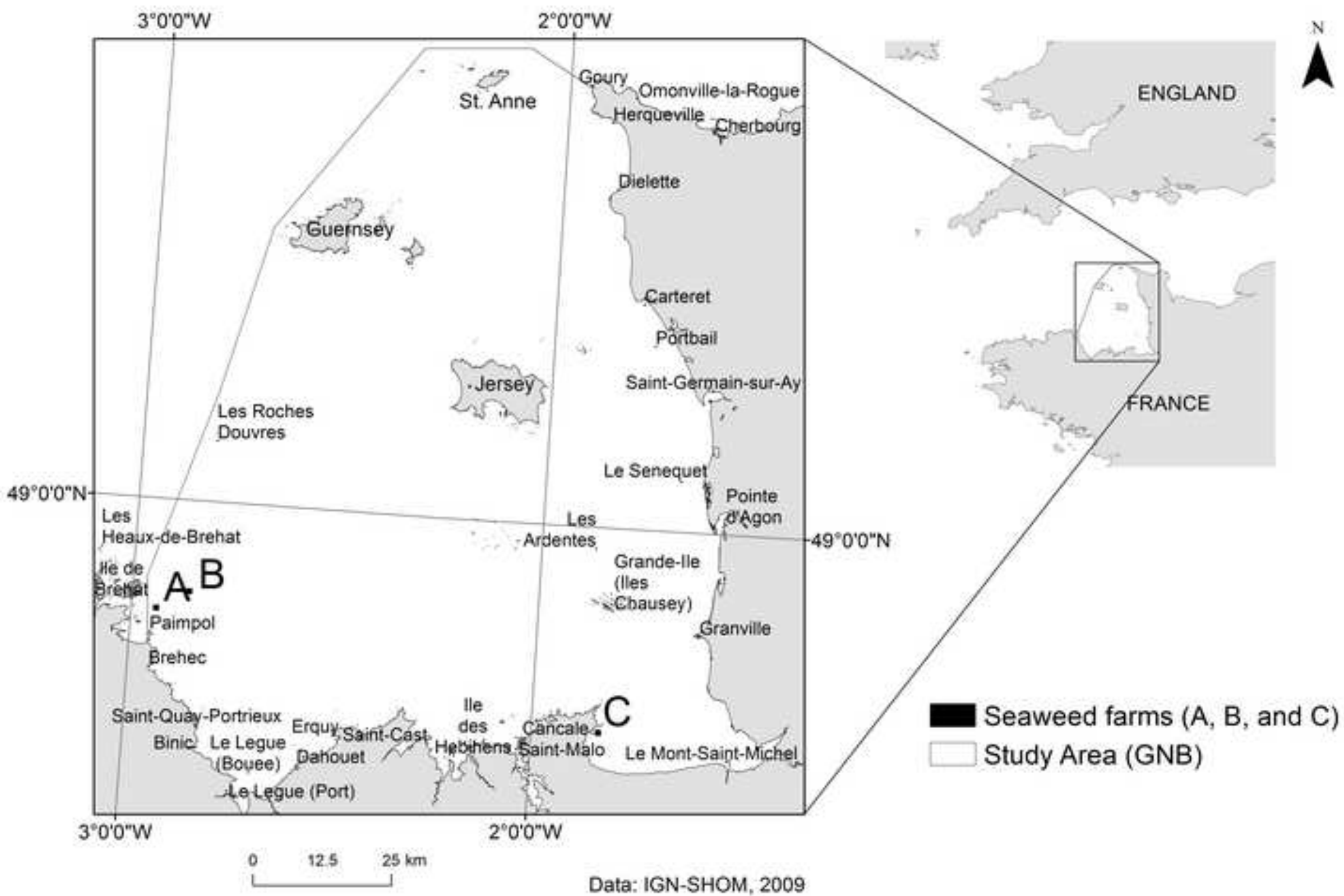

Data: IGN-SHOM, 2009 


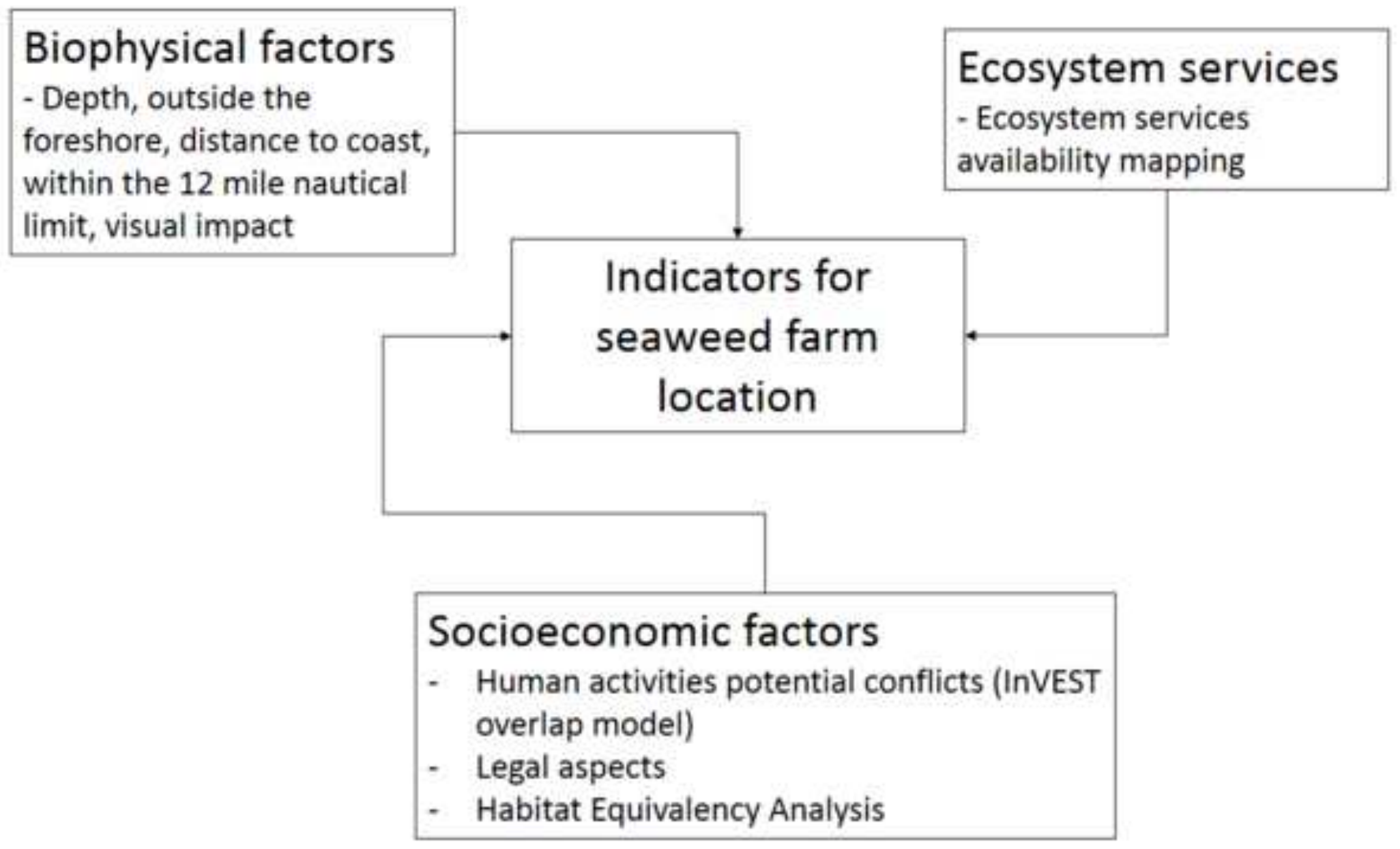


Figure 3

Click here to download high resolution image

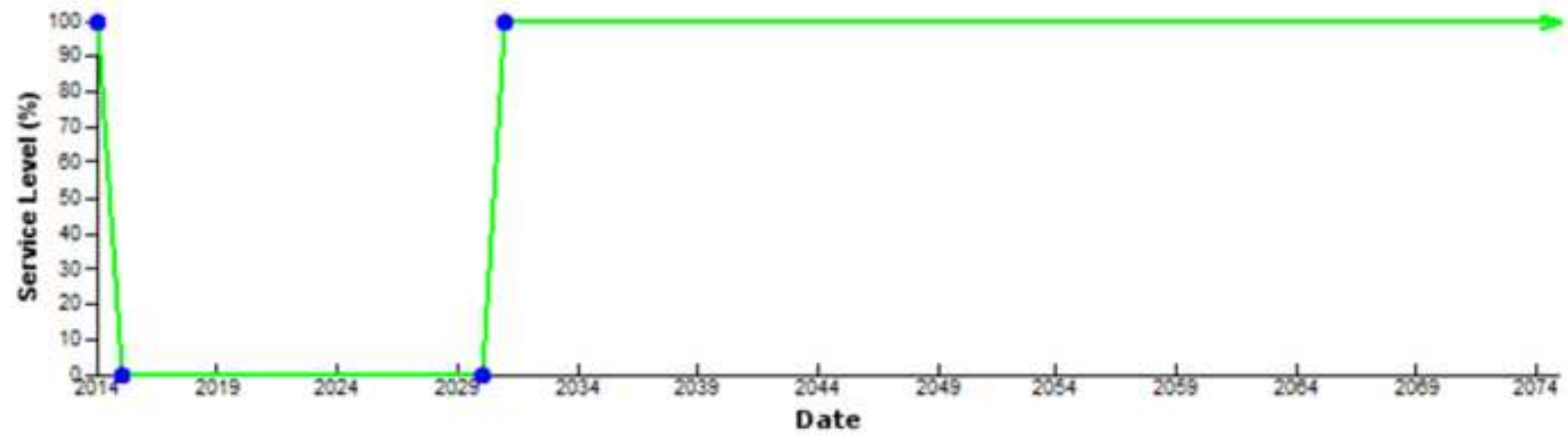


Figure 4

Click here to download high resolution image

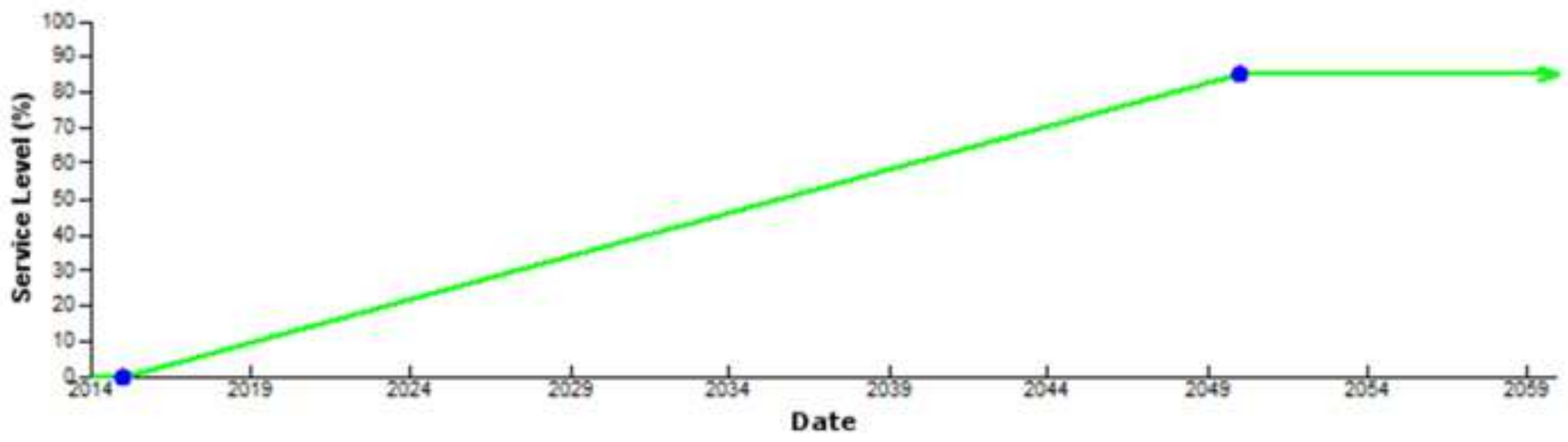




\section{Figure 5}

Click here to download high resolution image

Value
\begin{tabular}{|l|l}
\hline & $1-2$ \\
3 \\
$\square$ \\
$\square$ \\
$\square$
\end{tabular}

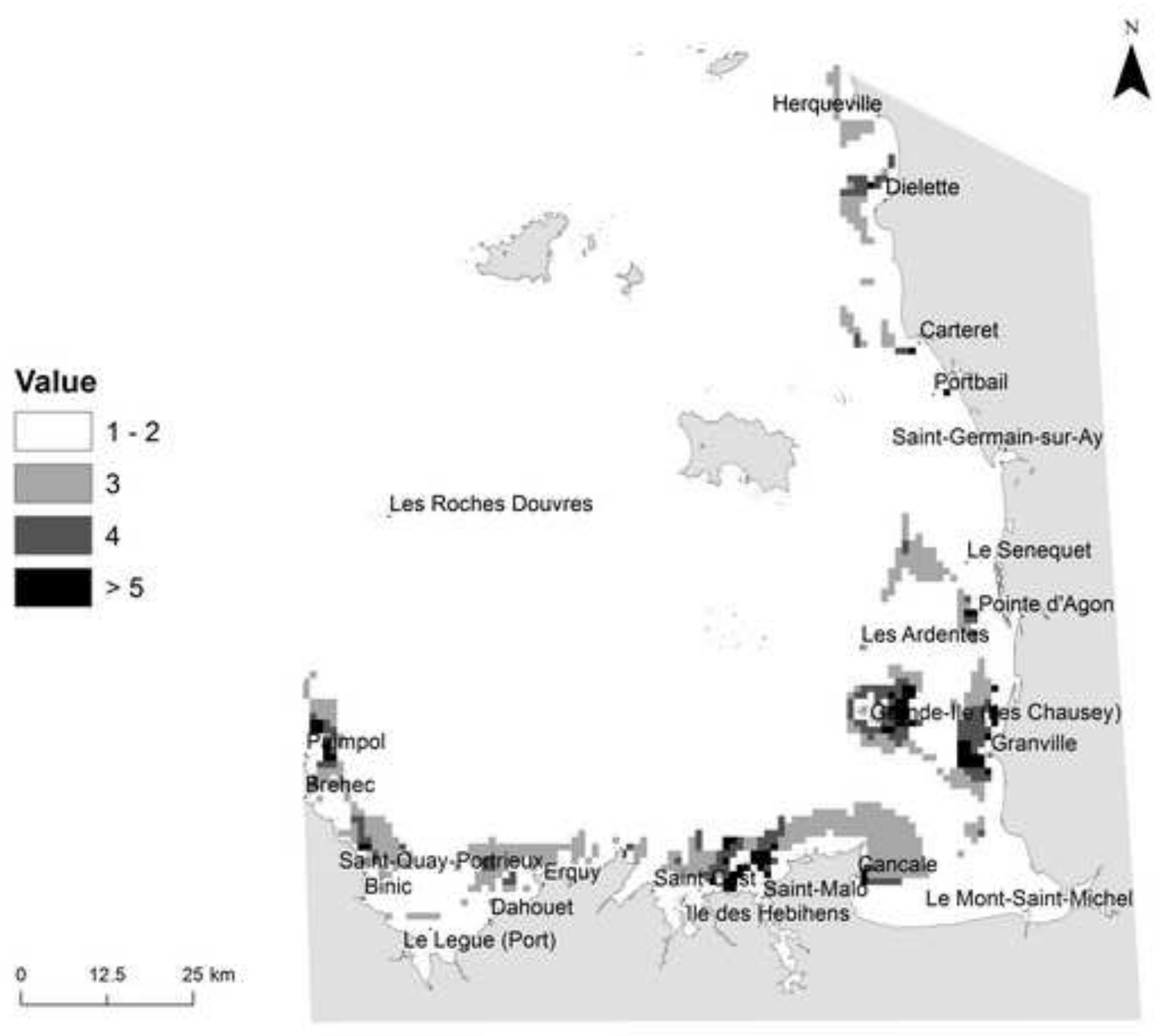




\section{Provisioning \\ services}

\section{ES availability}

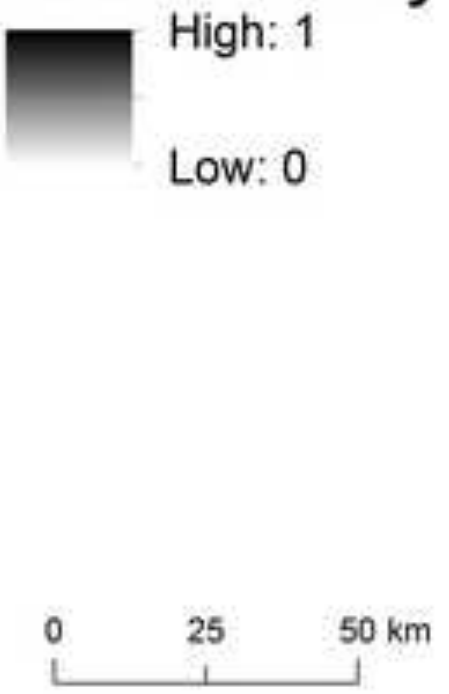

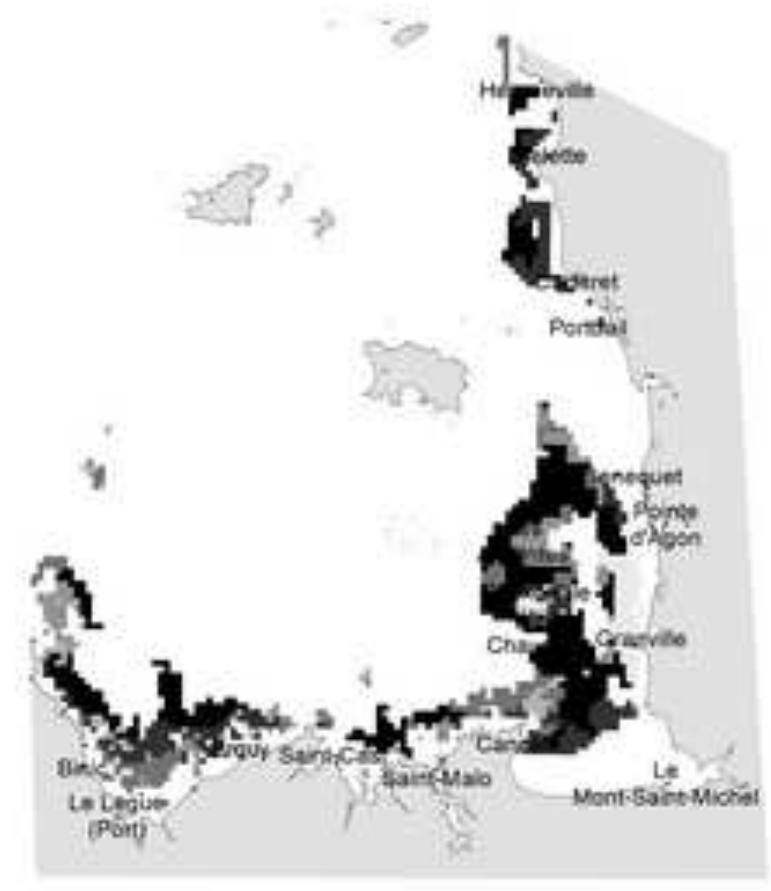
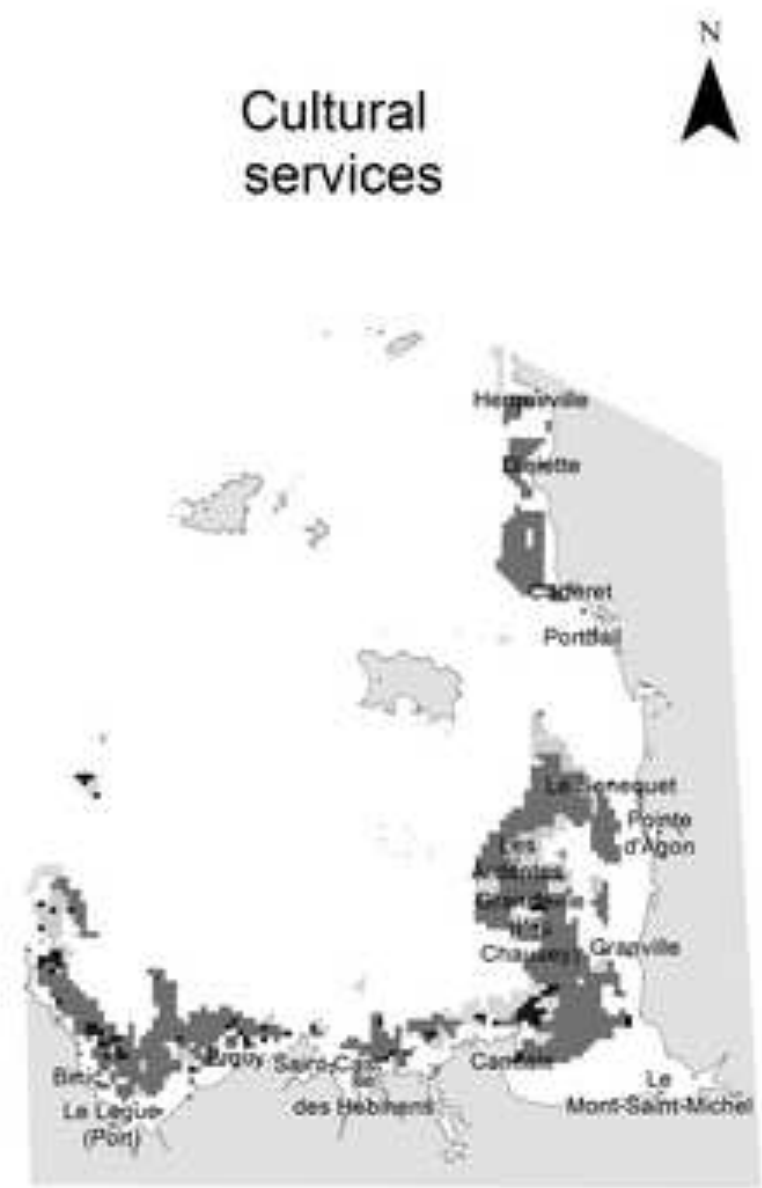


\section{Figure captions list}

Fig. 1. The Normand-Breton (Saint Malo) Gulf and the hypothetical location of 3 seaweed farms (A, B, and C)

Fig. 2. Methodological approach

Fig. 3. Service level provided at the injury site

Figure 4. Service level as a result of the compensatory action provided for maerl beds

Fig. 5. Human activities potential conflicts within the suitable area

Fig. 6. Provisioning and cultural ES availability in the GNB 
Table 1 Provisioning and cultural ES identified for the GNB habitats and studied here (adapted from [27])

\begin{tabular}{cl}
\hline Type & Ecosystem Service \\
\hline Provisioning & Food provision \\
& Raw material \\
Cultural & Cultural heritage and identity \\
& Cognitive benefits \\
& Recreation \\
& Notable biodiversity \\
\hline
\end{tabular}


Table 2 Types of habitats and main species for each seaweed farm. Proxies for ecosystem services indicators were selected according to the highest intensity of presence (3)

\begin{tabular}{|c|c|c|c|c|}
\hline $\begin{array}{c}\text { Seaweed } \\
\text { farm }\end{array}$ & Habitats (\% overlap) & Species intensity of presence & Selected proxy & $\begin{array}{l}\text { Ecosystem } \\
\text { service } \\
\text { category }\end{array}$ \\
\hline A & A5.51 - Maerl beds (100\%) & $\begin{array}{l}\text { Scallops (1), Clams (2), Pink clam and } \\
\text { sea almond (2), Maerl (3) }\end{array}$ & Maerl & Cultural \\
\hline B & $\begin{array}{l}\text { A5.13 - Circalittoral coarse } \\
\text { sediment }(100 \%)\end{array}$ & $\begin{array}{l}\text { Scallops ( (3), Clams (2), Pink clam } \\
\text { and sea almond (2), Whelk (3), Soles } \\
\text { (2), Pétoncles vanneau (2), Bass (2) }\end{array}$ & $\begin{array}{l}\text { Scallops } \\
\text { (Pecten } \\
\text { maximus) }\end{array}$ & Provisioning \\
\hline \multirow{2}{*}{$\mathrm{C}$} & $\begin{array}{c}\text { A2.24 - Polychaete/bivalve- } \\
\text { dominated muddy sand } \\
\text { shores }(38.4 \%)\end{array}$ & $\begin{array}{c}\text { Pacific oysters (3), Mussels (3), } \\
\text { Manila clams (2) }\end{array}$ & $\begin{array}{c}\text { Mussels } \\
\text { (Mytilus edulis) }\end{array}$ & \\
\hline & $\begin{array}{l}\text { A5.43 - Infralittoral mixed } \\
\text { sediments }(61.6 \%)\end{array}$ & $\begin{array}{c}\text { European oyster (3), Scallops (1), } \\
\text { Crepidula (1) }\end{array}$ & $\begin{array}{l}\text { European } \\
\text { oyster (Ostrea } \\
\text { edulis) }\end{array}$ & \\
\hline
\end{tabular}


Table 3 Types of habitats and main species for each seaweed farm. Proxies for ecosystem services indicators were selected according to the highest intensity of presence (3)

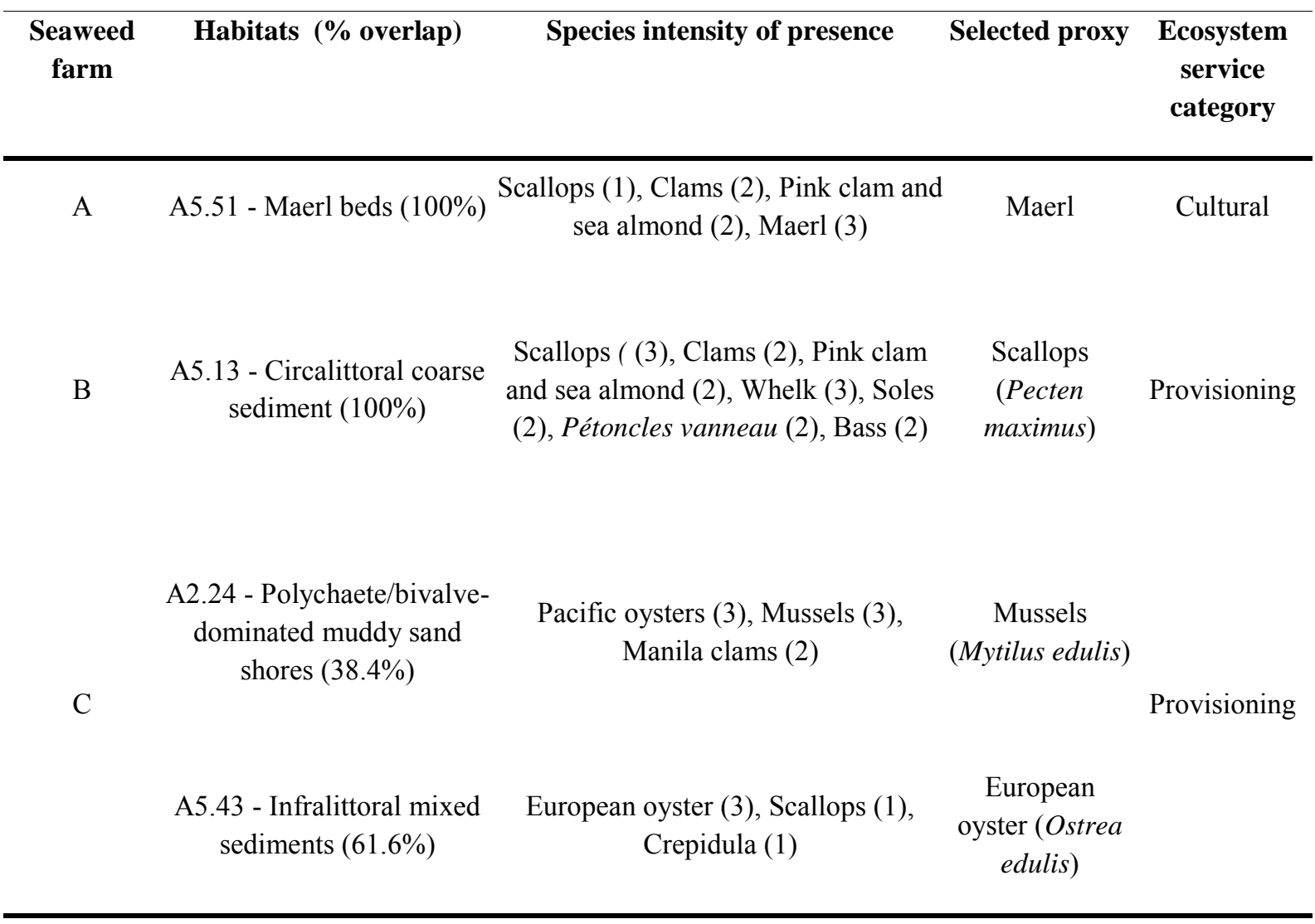


Table 4 Indicators for deploying seaweed farms

\begin{tabular}{|c|c|c|c|c|}
\hline Seaweed farm & $\mathbf{A}$ & B & \multicolumn{2}{|c|}{ C } \\
\hline Habitats (\%) & $\begin{array}{c}\text { A5.51 - Maerl beds } \\
(100 \%)\end{array}$ & $\begin{array}{l}\text { A5.13 - } \\
\text { Circalittoral } \\
\text { coarse sediment } \\
(100 \%)\end{array}$ & $\begin{array}{c}\text { A2.24 - } \\
\text { Polychaete/bivalve- } \\
\text { dominated muddy } \\
\text { sand shores }(38.4 \%)\end{array}$ & $\begin{array}{c}\text { A5.43 - } \\
\text { Infralittoral } \\
\text { mixed sediments } \\
(61.6 \%)\end{array}$ \\
\hline Proxy & Maerl beds & Scallops & Mussels & European oyster \\
\hline $\begin{array}{l}\text { Provisioning services } \\
\text { availability (\%) }\end{array}$ & 42 & 100 & 50 & \\
\hline $\begin{array}{l}\text { Cultural services } \\
\text { availability (\%) }\end{array}$ & 20 & 52 & 10 & \\
\hline Distance to coast (km) & 5.2 & 11.4 & 1 & \\
\hline $\begin{array}{l}\text { Potential human use } \\
\text { conflicts }\end{array}$ & 5 & 1 & 5 & \\
\hline Visual impact (inhab.) & 3690 & 9100 & 825 & \\
\hline $\begin{array}{l}\text { Ha compensation per } \\
\text { damaged ha }\end{array}$ & 2.585 & 2.290 & 2.00 & \\
\hline $\begin{array}{l}\text { Restoration cost per } \\
\text { farm of } 1 \mathrm{~km}^{2} \text { (USD) }\end{array}$ & $\$ 6,384,950-\$ 31,937,158$ & $\$ 365,484$ & $\$ 1,483,882-$ & $9,893,684$ \\
\hline
\end{tabular}


Table A.1 Professional and recreational activities geographical datasets

\begin{tabular}{|c|c|c|c|}
\hline GIS layers & Source & Type & Pre-processing \\
\hline Professional fishing & $\begin{array}{l}\text { Ifremer, } \\
\text { SIH, } 2012\end{array}$ & Polygon & $\begin{array}{l}\text { Density of ships per month per statistical sub- } \\
\text { rectangle. All engine types. Density }>0.2\end{array}$ \\
\hline $\begin{array}{l}\text { Dredge spoil dispposal } \\
\text { sites }\end{array}$ & AAMP & Point & Buffer of $1000 \mathrm{~m}$ \\
\hline Harbors & AAMP & Point & $\begin{array}{l}\text { Buffer according to number of ships: }<5=250 \mathrm{~m} ; \\
>=5 \text { and }<25=500 \mathrm{~m} ;>=25 \text { and }<100=1000 \mathrm{~m} ; \\
>=100=2000 \mathrm{~m}\end{array}$ \\
\hline Off-shore energy & AAMP & Polygon & None \\
\hline Marinas & AAMP & Point & Buffer of $250 \mathrm{~m}$ \\
\hline Anchorages & AAMP & Point & $\begin{array}{l}\text { Buffer according to the capacity: }<10=250 \mathrm{~m} ;> \\
=10 \text { and }<100=500 \mathrm{~m} ;>=100=2000 \mathrm{~m}\end{array}$ \\
\hline Shellfish farms & AAMP & Polygon & Convex hull for grouping shellfish records \\
\hline Granulate extraction & AAMP & Polygon & None \\
\hline Marine traffic & AAMP & Polyline & None \\
\hline $\begin{array}{l}\text { Recreational on-foot } \\
\text { fishing }\end{array}$ & AAMP & Polygon & Selection of the foreshore area \\
\hline $\begin{array}{l}\text { Recreational boat } \\
\text { fishing }\end{array}$ & AAMP & Point & $\begin{array}{l}\text { Buffer of } 3000 \mathrm{~m} \text { around points and inside the } \\
\text { sailing areas }\end{array}$ \\
\hline Surfing & AAMP & Polyline & Buffer of $250 \mathrm{~m}$ \\
\hline Kitesurfing & AAMP & Point & Buffer of $1 \mathrm{~km}$ \\
\hline Sailing & AAMP & Point & Buffer of $1 \mathrm{~km}$ in the navigation area \\
\hline Land sailing & AAMP & Point & Buffer of $5 \mathrm{~km}$ in the foreshore \\
\hline Scuba diving & AAMP & Point & Buffer of $250 \mathrm{~m}$ \\
\hline Sea rowing & AAMP & Polyline & Buffer of $5 \mathrm{~km}$ \\
\hline
\end{tabular}

